\title{
DIFFERENCES IN INFLUENCES BY THE SECOND ORDER THEORY DEPENDING ON MEMBERS CROSS SECTIONS
}

\author{
Slavko Zdravković \\ Faculty of Civil Engineering and Architecture, University of Nis, Serbia \\ Tomislav Igić \\ Faculty of Civil Engineering and Architecture, University of Nis, Serbia \\ Marina Mijalković \\ Faculty of Civil Engineering and Architecture, University of Nis, Serbia \\ Milovan Stanojev \\ Faculty of Civil Engineering and Architecture, University of Nis, Serbia
}

In this paper Second order theory is derived from deformation method. In given numerical examples (1 and 2) it has been shown that for the same values of normal forces in members, for the same lengths of the members of the system and for the same modulus of elasticity $E$, but for the different dimensions of cross sections, very different influences are obtained. Calculated values of bending moments differ very little, if the cross section of the member system is closer to real value, than that of the cross-section of members which are closer to the system stability limit. The greater the member rigidity, the smaller the differences in influences and displacements calculated according to linearized and accurate Second order theory.

Key words: Second order theory, Members, Cross sections

\section{INTRODUCTION}

First order theory, i.e. linear structural statics, such as is used in everyday engineering practice, is based on three basic assumptions [01]:

1. Assumption that the strain of $\varepsilon$ axis of the member and rotation $\varphi$ of the cross section of the member, and their derivations are small values whose squares and higher powers can be neglected. Therefore, this assumption considers $\varepsilon<<1$ and $\varphi<<1$. For this reason, it is called the assumption of small deformations. This assumption provides geometrical linearity in solving the tasks of structural statics.

2. Assumption that the values of displacement of the impact points of external forces on the girder and internal forces are small in respect to the basic dimensions of the girder. For this reason it is called the assumptions of small displacement values of impact points of external and internal forces. This assumption provides static linearity, because in the equilibrium conditions, the displacements of impact points of the external forces on the girder and of the interior forces are neglected, that is, the equilibrium conditions are written on the unstrained girder [2].

3. The assumption of the linear relation between the strain and stress, that is, temperature changes.

The assumption provides physical linearity when solving the tasks of structural statics, which set by the Hooke's law [02].

Finite deformation theory rejects first two of the previously laid down assumptions, and retains only the third assumption of the physical linearity of the problem.

The second order theory rejects only second of the previously mentioned assumptions, and retains the first and the third assumption. The need not to neglect the displacement of impact points, that is, justifiability of writing the equilibrium conditions on the strained girder will best be observed in the following example.

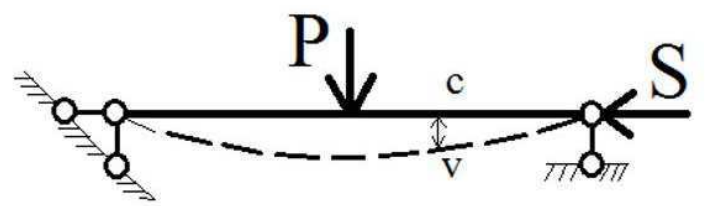

Figure: 1 Principle of second order theory 
If we consider the equilibrium of unstrained simple beam, in Figure 1, force $S$ does not affect the values of bending moments in transverse cross sections of the beam. However, by considering the equilibrium of strained simple beam (second order theory), the bending moment in arbitrary cross section [3] has the value:

$M_{c}=M_{c 0}+S \cdot v$

Where $M_{c 0}$ is the bending moment of the simple beam loaded only by transverse loads.

Member S.v can have significant value for higher axial load $S$ even at small deflections. On the other hand, the member S.v causes further increase of deflection of the simple beam, which proportionately increases the value of moment $M_{c}$.

Therefore, by calculating the simple beam, in Figure 1, according to the linear theory, we reduce the safety coefficients of the girder.

\section{LINEARIZED SECOND ORDER THEORY}

The system of equations according to the second order theory can be linearized, at least according to the unknown parameters, starting from the assumption that the product of static and strain unknown is equal to the product of the same unknowns [4], where the static unknown is determined according to the linear theory:

$$
S \cdot U=S_{0} \cdot U
$$

In this way, the linearized theory of second order is obtained, whose equation system is:

$$
\begin{aligned}
& d u=\varepsilon d x \\
& d v=\varphi d x \\
& d H+p_{x} d x=0 \\
& d V+p_{y} d x=0 \\
& d M-V d x-V_{0} d u+H_{0} d v=0 \\
& \frac{d \varphi}{d x}=-\frac{M}{E I}-\alpha_{t} \cdot \frac{\Delta t}{h} \\
& \varepsilon=\frac{N}{E F}+\alpha_{t} \cdot t^{o}=\frac{1}{E F}\left(H+V_{o} \varphi\right)+\alpha_{t} \cdot t^{o}
\end{aligned}
$$

If it is the case of one straight member with set limit conditions, then we can determine force $\mathrm{H}$, so the problem of nonlinearity is solved. For the problems of member systems, determination of normal forces cannot be separated from the de- termination of transversal forces, and in turn, they depend on the moments in the adjacent members. Therefore, instead of force $\mathrm{H}$ force $\mathrm{H}_{0}$ is adopted. According to the second order theory, the system equilibrium is established on the strained system, which actually happens in reality.

\section{APPLICATION OF THE STRAIN METHOD IN THE CALCULATION OF THE SYSTEM OF MEMBERS ACCORDING TO THE SECOND ORDER THEORY}

Basic equations of the strain method

The expression for the member restrained at one end is [04]:

$$
\begin{aligned}
& M_{i g}=d_{i g} \varphi_{i}-d_{i g} \grave{\mathrm{E}}_{i g}+\overline{\mathfrak{M}}_{i g} \\
& d_{i g}=\frac{E I}{L} \cdot \frac{\omega^{2} \sin \omega}{\sin \omega-\omega \cos \omega}
\end{aligned}
$$

where: $\omega=k L=L \sqrt{\frac{S}{E I}}$.

Apart from the members restrained on both ends and one end, in the second order theory the concept of elastically restrained consoles is introduced. Rotation of the node $\varphi_{i}$ in which such member is restrained, changes the restriction moment.

The expression for the moment on the end $i$, of the console is, can be written in the form:

$M_{i s}=e_{i s} \varphi_{i}+\overline{\overline{\mathfrak{M}}}_{i s}$

Parameters $\mathrm{d}_{\mathrm{ig}}$ and $\mathrm{e}_{\text {is }}$ are calculated of one determinate value of axial force $S$, due to the limited validity of the superposition principle.

The rigid restrainment $\overline{\mathfrak{M}}_{i g}$ is:

$\overline{\mathfrak{M}}_{i g}=\mathfrak{M}_{i g}-\frac{b_{i g}}{a_{i g}} \mathfrak{M}_{g i}$

Conditional equations for determination of strain Indeterminate parameters

With the expression 4 and 5 we defined the moments of so called ,,g" type members and ,,s" type console members according to the second order theory [3]. The number of strain indeterminate parameters is equal to $m+n$, where $m$ is the number of unknown rotations of nodes $\varphi_{i}(\mathrm{i}=1,2, \ldots, \mathrm{m})$, and nis the number of degrees of freedom $\Delta_{j}(j=1,2, \ldots$ ,n) of the system grid. The concept angles of node rotation whose number is equal to the number of groups of rigidly connected members), as well as the notion of the system grid were introduced in 
the approximate strain method according to the first order theory. Whereby the number of unknown displacement parameters $\Delta_{\mathrm{j}}(\mathrm{j}=1,2, \ldots, \mathrm{n})$ is determined by static kinematic considerations in the system called the grid of the given girder, and it is equal to the number of degrees of freedom of displacement of this grid.

$$
\begin{aligned}
& M_{i g}=d_{i g} \varphi_{i}-d_{i g} \sum_{j=1}^{n} \Delta_{j} \psi_{i g . j}+\overline{\mathfrak{M}}_{i g} \\
& d_{i g}=\frac{E I}{L} \cdot \frac{\omega^{2} \sin \omega}{\sin \omega-\omega \cos \omega}=\frac{E I}{L} \bar{d} \\
& M_{i s}=e_{i s} \varphi_{i}+\overline{\mathfrak{M}}_{i s} \\
& e_{i s}=-\frac{E I}{L} \omega \cdot \operatorname{tg} \omega=\frac{E I}{L} \bar{e}
\end{aligned}
$$

Where the coefficients of the members are functions of the characteristical cross-sections, spans and values of axial forces of members, while in linear theory, those were constants of the members with the constant cross-sections.

For determination of all strain unknowns, a mequation of rotation of nodes with rigid angles should be composed, as well as $n$ equation of displacement of joint figures.

Conditional equations for determination of strain indeterminate parameters

If in the equations of node rotations which have rigid angles, which formally do not differ from the equations in linear theory, since the equilibrium of moments of all nodes is required, the expression for moments on the ends of members are included, we will obtain a system of m-equations with $m+n$ deformation unknown values $\varphi_{i}$ and $\Delta_{i}$ :

$A_{i i} \varphi_{i}+\sum_{k} A_{i k} \varphi_{k}+\sum_{j=1}^{n} B_{i j} \Delta_{j}+A_{i o}=0$

$(i=1,2, \ldots, m)$

Displacement equations

When writing the equations, we make a requirement that the algebraic sum of works of all external forces on each virtual displacement of the joint figure is equal to zero, whereby displacement of impact points of external forces must not be neglected.

By comparing the basic equations of equilibrium of differential element of the member written in the second order theory and the linear theory [03], we will conclude that the influences according to the second order theory can be determined according to the linear theory [02], if the considered element of the member, is subjected also to the action of fictitious distributed moments, apart from the given load.

$m^{f}=H \frac{d v}{d x}=H v^{\prime}=H_{o} v^{\prime}=N_{o} v^{\prime}$

Linearization of the task is performed by simplification according to which the axial force $\mathrm{H}=\mathrm{H}_{0}$ is determined from the linear theory task, or even from the figure of joints if it can be even in the precarious equilibrium with the set external forces.

For the value of work of distributed fictitious moments $\mathrm{m}^{\mathrm{f}}$ on the displacements $\Delta_{\mathrm{j}}$ the following is obtained:

$R_{j}\left(m^{f}\right)= \pm \sum_{a b} \omega_{a b}^{2} \frac{E I_{a b}}{L_{a b}} \Psi_{\mathrm{ab}, \mathrm{j}}-$

$\sum_{\mathrm{L}=\mathrm{i}}^{\mathrm{n}} \Psi_{\mathrm{ab}, \mathrm{L}} \Delta_{\mathrm{L}}+\Psi_{0}+\Psi_{\mathrm{ab}, \mathrm{c}}$

Whereby the + sign should be assumed when $\mathrm{N}_{(0, a b)}$ is negative, provided that in the sum $\Sigma_{a b}$ there are not console members ne (type s) included.

When in the displacement equations the expressions for the moments on the ends of the members are included, as well as the expression for the work of distributed moments, then the following form of the displacement equation is obtained:

$\sum_{i=1}^{n} B_{j i}^{\prime} \varphi_{i}+\sum_{L=1}^{n} C_{j L} \Delta_{L}+C_{j 0}=0$

In equations 14 and 15 the moments on the ends of the ,g" type members and ,s" type members expressed by $m+n$ indeterminate (unknown) deformation values $\varphi_{i}(i=1,2, \ldots, m)$ and $\Delta_{i}(j=1,2, \ldots$ ,n), are unknown and they will be determined from the $m+n$ conditional equations. These conditional equations, as opposed to the first order theory, should be written now on the strained girder.

By introducing the following designations [06]:

$A_{i i}=\sum_{k} a_{i k}+\sum_{g} d_{i g}+\sum_{s} e_{i s}$

$\sum_{k} a_{i k} A_{i k}=b_{i k}=0 \quad i \neq k$

$B_{i j}=B_{i j}^{\prime}=-\sum_{k} c_{i k} \psi_{i k, j}-\sum_{g} d_{i g} \psi_{i g, j}$

$c_{i k}=0$

$C_{j l}=\sum_{i k}\left(c_{i k}+c_{k i}\right) \psi_{i k, j} \psi_{i k, l+}$

$+\sum_{i g} d_{i g} \psi_{i g, j} \psi_{i g, l} \mp E I_{c} \sum_{a b} \frac{\omega_{a b}^{2}}{L_{a b}^{\prime}} \psi_{a b, j} \psi_{a b, l}$ 


$$
\begin{aligned}
& A_{0 i}=\sum_{k} \mathfrak{M}_{i k}+\sum_{g} \overline{\mathfrak{M}_{\imath g}}+\sum_{s} \overline{\overline{\mathfrak{M}_{l s}}} \\
& C_{0 j}=-\sum_{i k}\left(\mathfrak{M}_{i k}+\mathfrak{M}_{k i}\right) \psi_{i k, j}- \\
& \sum_{i g} \overline{\mathfrak{M}_{\imath g}} \psi_{i g, j} \mp \\
& \mp E I_{c} \sum_{a b} \frac{\omega_{a b}^{2}}{L_{a b}^{\prime}}\left(\psi_{a b, t}+\psi_{a b, c}\right) \psi_{a b, j}-R_{j}(p)
\end{aligned}
$$

The constant equations, i.e. node rotation equations and displacement equations finally assume the form:

$$
\begin{aligned}
& A_{i i} \varphi_{i}+\sum_{k} A_{i k} \varphi_{k}+\sum_{j=1}^{n} B_{i j} \Delta_{j}+A_{0 i}=0 \\
& \sum_{i=1}^{n} B_{j i}^{\prime} \varphi_{i}+\sum_{l=1}^{n} C_{j l} \Delta_{l}+C_{0 j} \\
& (i=1,2, \ldots, m)(j=1,2, \ldots, n)
\end{aligned}
$$

Member constants $d_{i g}$ and $e_{i s}$ as well as the restrainment moments $\mathfrak{M}_{i k}, \overline{\mathfrak{M}}_{i g}$ and $\overline{\mathfrak{M}_{l s}}$ (accordingly the parameters $A_{0 i}$ ) in the expressions from 16 to 20 depend on the normal forces in the girder members, while in the first order theory these values did not depend on the normal forces in the girder members.

Diagonal elements $A_{i j}$ of the square matrix $A$ contain the constants $e_{i s}$ of the ,,s" type members, which is not the case in the first order theory.

In elements $\mathrm{C}_{\mathrm{jl}}$ of the matrix $\mathrm{C}$, according to the adopted marking, the new terms

$\mp E I_{c} \sum_{a b} \frac{\omega_{a b}^{2}}{L_{a b}^{\prime}} \psi_{a b, j} \psi_{a b, l}$

are introduced, which do not exist in the first order theory.

Finally, the difference between the first and second order theory reflects in the elements $\mathrm{C}_{\mathrm{oj}}$ of the matrix $\mathrm{C}_{\mathrm{oj}}$, which in the second order theory have the following addition

$$
\mp E I_{c} \sum_{a b} \frac{\omega_{a b}^{2}}{L_{a b}^{\prime}}\left(\psi_{a b, t}+\psi_{a b, c}\right) \psi_{a b, j}
$$

\section{NUMERICAL EXAMPLES}

1) Let us calculate the values of the bending moment on the ends of the members of the given system, according to the second order theory, if the support 4 is displaced for $\mathrm{c}_{\mathrm{v}}=2 \mathrm{~cm}$ downwards. The values in the members should be taken from the grid of the system.
a) $\mathrm{b} / \mathrm{h}=25 / 40 \mathrm{~cm} / \mathrm{cm}$
$E=3 \cdot 10^{7} \frac{\mathrm{kN}}{\mathrm{m}^{2}}$
$E I=40000 \mathrm{kNm}^{2}$

\section{Normal force values}

$\mathrm{N}_{15}=-500 \mathrm{kN}$

$\mathrm{N}_{14}=-500 \mathrm{kN}$

$\mathrm{N}_{12}=\mathrm{N}_{23}=0 \mathrm{kN}$

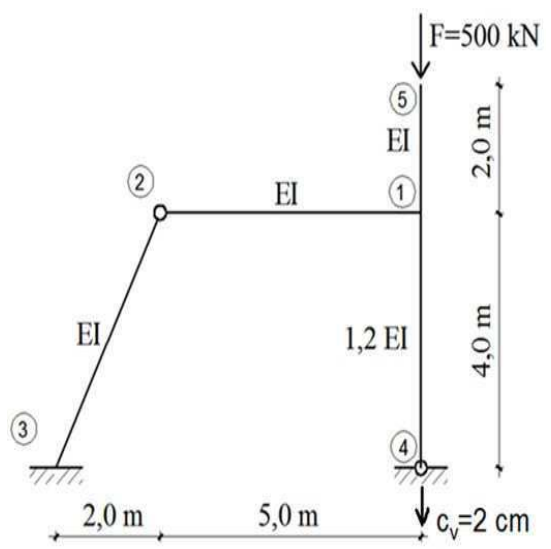

Figure: 2 Static system

The system is doubly indeterminate in terms of strain $\left(\varphi_{1}\right.$ and $\left.\Delta_{1}\right)$, so the conditional equations are:

$A_{11} \varphi_{1}+B_{11} \Delta_{1}+A_{10}=0$

$\underline{B}_{11}^{\prime} \varphi_{1}+C_{11} \underline{\Delta}_{1}+C_{10}=0$

$A_{11}=d_{12}+d_{14}+e_{15}$

$B_{11}=B_{11}^{\prime}=-d_{12} \Psi_{12,1}-d_{14} \Psi_{14,1}$

$\mathrm{C}_{11}=d_{12} \Psi_{12,1}{ }^{2}+d_{14} \Psi_{14,1}{ }^{2}+$

$+d_{32} \Psi_{32,1}{ }^{2}-\frac{1,2 E I}{4} \omega_{14}{ }^{2} \Psi_{14,1}{ }^{2}$

The coefficients along the unknowns in the conditional equation are calculated depending on the value $\omega$ :

$\omega_{15}=0,2236$

$\omega_{14}=0,4080$

$\omega_{12}=\omega_{32}=0$

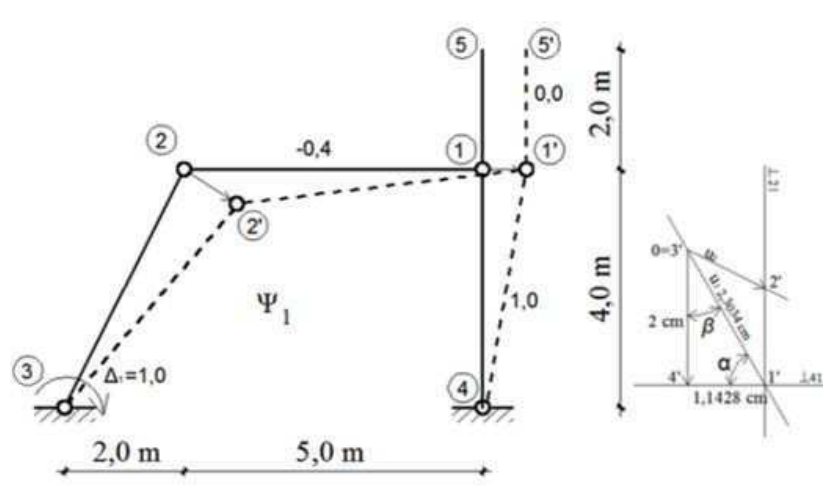

Figure 3: Displacement status $\Delta_{1}=1$ 


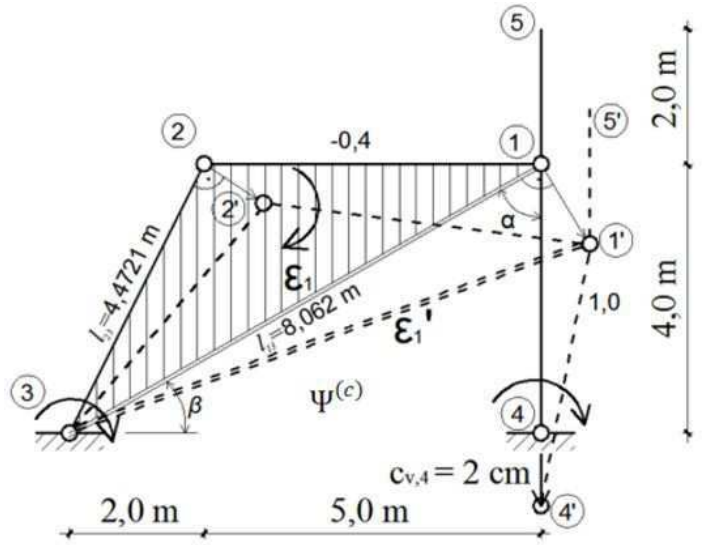

Figure 4: Figure of nodes

$\Psi_{12}=\Psi_{32}=\Psi_{14}=2,857 \cdot 10^{3}$

$\Psi_{15}=0$

In order to calculate coefficient $A_{10}$ and $C_{10}$ one should determine the rotation angles of the stable figure of joints at displacement $c_{v 4}=2,0 \mathrm{~cm}$, and then find the moments of full restraint. Displacement of nodes and rotation of members of the stable joint figure (node figure) are usually find applying Villiot's displacement plan or with poles and medium poles.

Conditional equations of the strain method.

$$
1,4645 E I \varphi_{1}-0,650 E I \Delta_{1}-96,0=0
$$

$\varphi_{1}=\frac{92,8164}{\mathrm{EI}} \quad \Delta_{1}=\frac{61,4457}{\mathrm{EI}}$

$-0,650 E I \varphi_{1}+1,6068 E I \Delta_{1}-38,4=0$

Displacement of node 5 is $11,17 \mathrm{~mm}$.

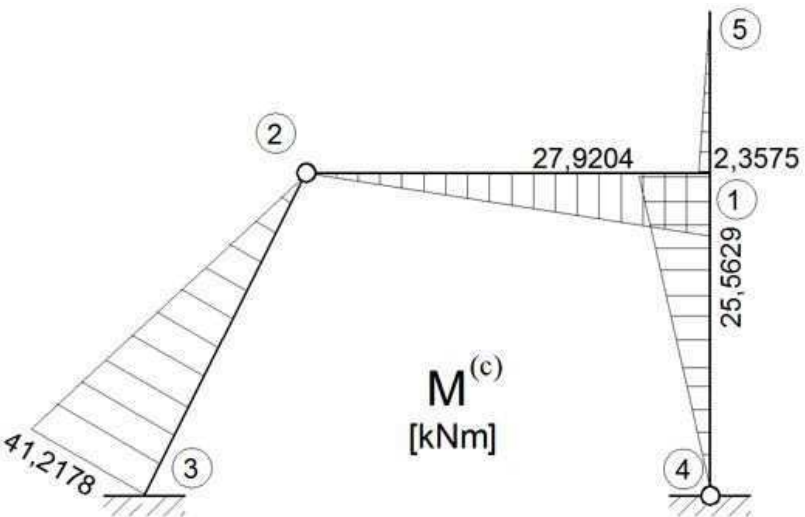

Figure 5: Diagram of bending moment

2) For the system given in the example 1 ie. for the same load and lengths of the members, let us calculate the bending moments in the case of various stiffness of all members [01]. a) $b / h=20 / 20 \frac{\mathrm{cm}}{\mathrm{cm}}$

$E=3 \cdot 10^{7} \mathrm{kN} / \mathrm{m}^{2}$

$E I=4000 \mathrm{kNm}^{2}$

Normal forces values

$\mathrm{N}_{15}=-500 \mathrm{kN}$

$\mathrm{N}_{14}=-500 \mathrm{kN}$

$\mathrm{N}_{12}=\mathrm{N}_{23}=0 \mathrm{kN}$

The coefficients along the unknowns in the conditional equation are calculated depending on the value $\omega$ :

$\omega_{14}=1,291 \quad \omega_{15}=0,707 \quad \omega_{12}=\omega_{32}=0$

Conditional equations of the strain method.

$1,4645 \mathrm{EI} \varphi_{1}-0,650 \mathrm{EI} \Delta_{1}-9,6=0$

$\varphi_{1}=14,4596 / \mathrm{EI} \Delta_{1}=11,1680 / \mathrm{EI}$

$-0,650 \mathrm{El} \varphi_{1}+1,6068 \mathrm{EI} \Delta_{1}-3,84=0$

Displacement of node 5 is $21,34 \mathrm{~mm}$.

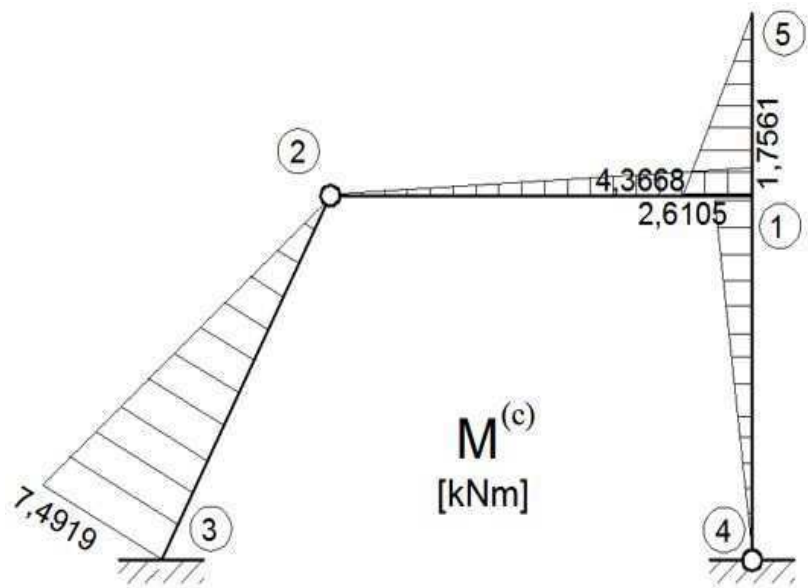

Figure 6: Diagram of bending moment

\section{CONCLUSION}

In the previously given numerical examples (1 and 2), as already know, it has been shown that for the same values of normal forces in members, for the same lengths of the members of the system and for the same modulus of elasticity $\mathrm{E}$, but for the different dimensions of cross sections, very different influences are obtained, in this case the bending moments at the ends of the members and displacement of cantilever top. The values of bending moments in the restraint (node 3) differ (Fig. 5 and 6) only because of different cross-sections (25/40 and $20 / 20 \mathrm{~cm}$ ) for $550 \%$. Along the member $2-3$ the diagram 
of bending moment even changes the operator (side of tension) and it differs for $1455 \%$. In case there is no displacement of support 4 for $2 \mathrm{~cm}$ the difference in node 1 is $31,93 \%$, and the bending moments along the member 2-3 the operator is changed. Difference between displacements of node 5 in case 1 and in case 2 is $191 \%$.

The greater the member rigidity, the smaller the differences in the influences calculated according to linearized and accurate Second order theory.

\section{ACKNOWLEDGEMENTS}

This research is conducted at Faculty of Civil Engineering and Architecture of University of Niš in the framework of the Project in the field of technological development in the period 2011-2014 (TR 36016 and TR 36028), financially supported by the Ministry of Education, Science and Tehnological development of the Republic of Serbia.

\section{REFERENCES}

1) Čaušević, M., \& Bulić, M. (2013). Stability of structures. Zagreb: Golden marketing.

2) Čaušević, M., Zdravković, S., \& Mundžić, E. (1992). Statika i stabilnost konstrukcija po teoriji drugog reda. Sarajevo: Svjetlost.

3) Đurić, M. (1973). Stabilnost i dinamika konstrukcija. Beograd: Skriptarnica Saveza studenata Građevinskog fakulteta.

4) Đurić, M., \& Jovanović, P. (2002). Teorija okvirnih konstrukcija. Beograd: Građevinska knjiga.

Paper sent to revision: 02.02.2015.

Paper ready for publication: 01.02.2016. 


\section{RAZLIKE U UTICAJIMA TEORIJA DRUGOG REDA U ZAVISNOSTI OD ČLANOVA PRESEKA}

Slavko Zdravković, Univerzitet u Nišu, Građevinsko-Arhitektonski fakultet, Niš Tomislav Igić, Univerzitet u Nišu, Građevinsko-Arhitektonski fakultet, Niš Marina Mijalković, Univerzitet u Nišu, Građevinsko-Arhitektonski fakultet, Niš Milovan Stanojev, Univerzitet u Nišu, Građevinsko-Arhitektonski fakultet, Niš

$U$ ovom radu teorija Drugog reda potiče od metoda deformacije. $U$ datim numeričkim primerima (1 i 2) je pokazano da za iste vrednosti normalnih sila u članovima, za iste dužine članova sistema i za isti modul elastičnosti $E$, ali za različite dimenzije preseka, se dobijaju veoma različiti uticaji. Izračunate vrednosti momenata savijanja se veoma malo, ako je presek sistema član bliže stvarnoj vrednosti, nego ako su članovi poprečnog preseka koji su bliže granici stabilnosti sistema. Što je veća rigidnost člana, to su manje razlike u uticajima i pomeranjima izračunatih u skladu sa linearizovanom i preciznom teorijom drugog reda.

Klučne reči: Teorija drugog reda, Članovi, Preseci 